\title{
Moult cycle and growth of Antarctic krill Euphausia superba in the laboratory
}

\author{
Friedrich Buchholz \\ Institut für Meereskunde an der Universität Kiel, Department of Marine Zoology, Düsternbrooker Weg 20, D-2300 Kiel, \\ Germany
}

\begin{abstract}
Using systems for long-term maintenance of Antarctic krill Euphausia superba in aquaria, positive growth was measured in a large number of specimens under controlled conditions. The first moult always showed the greatest growth increment. The high laboratory growth rates agreed with previous field investigations. Often-reported abnormal' slow and predominantly negative growth was probably due to inadequate maintenance procedures. Moulting was partly synchronous, and moult frequency was temperature dependent. Growth of Antarctic krill did not match the slow rates expected of a polar species. Krill was very sensitive to experimental variation in feeding regime: (1) moult frequency (14 to 29 d) and (2) growth increment at moult ( -15 to $21 \%$ ) varied together. Ecdysis and the staging and timing of the moult cycle were studied. The stage definitions of Buchholz (1982; Mar. Biol. 66: 301-305) were expanded and are now applicable to frozen krill and for field investigations, and include a simple classification key. Regular histological changes in the integument and consistent changes in the titre of the moult hormone could be attributed to distinct stages of the moult cycle. A clear temporal correlation confirmed the physiological relevance of the staging system. A possible 'resting' stage between post- and pre-ecdysis was not found. The apparent plasticity of growth parameters indicates that, in the wild, krill is able to adapt to strong regional and seasonal changes in feeding conditions, typical for Antarctic waters. Krill grows fast, and in spite of being predominantly planktonic, attains a large size. This enables fast swimming which facilitates location of rich food sources. Favourable feeding conditions immediately initiate growth. Essentially unhindered motility during actual moult and extremely fast ecdysis were interpreted as an adaptation to a pelagic way of life.
\end{abstract}

\section{INTRODUCTION}

Although many aspects of crustacean growth have been investigated (Hartnoll 1982), knowledge of moult cycles in conjunction with growth is still lacking in pelagic crustaceans, primarily because keeping such animals in captivity poses considerable problems. Antarctic krill Euphausia superba is truly pelagic and a well-suited subject for such studies since, under appropriate laboratory conditions, moulting occurs regularly and rapidly. Laboratory growth studies complement field investigations, although to date both approaches have produced inconclusive results (Siegel 1986, Buchholz et al. 1989). Information on growth rates and production of krill is important for management decisions regarding krill as a vast resource in the Southern Ocean (Hempel 1970)

Detailed knowledge of the moult cycle enables investigation of regular changes in the general biochemistry and morphology of a crustacean, and accordingly, the mechanisms that control moult and growth. Field studies of moult and growth are also feasible, once the timing of distinct moult phases is known (Buchholz 1985, Morris 1985). The basis of such studies is the moult staging system of Drach (1939) modified for euphausiids by Buchholz (1982). In the current work, the stage definitions are expanded and the underlying time course established. The reliability of the morphological staging method is verified by analysing the varying titre of the moult hormone, and describing the cyclical events in the integument, which itself is one of the most important target organs of the moult hormone.

Laboratory growth studies of Antarctic krill are numerous (see 'Discussion') but are mostly characterized by slow growth rates. Morris \& Keck (1984), however, showed that growth could be fast when maintenance conditions were improved. This study 
investigates this in more detail, concentrating on the 2 factors governing growth in crustaceans: the moult interval and the growth increment following moult. The effects of maintenance conditions were tested, using 2 different setups - an open circuit and a closed system. The influence of different feeding regimes on the moult parameters was also observed. The experiments supply information on the time course of the moult cycle under the conditions given, and are compared to a recent study which used a different methodology (Nicol \& Stolp 1990).

\section{MATERIAL AND METHODS}

Experiments were conducted at the Polish Antarctic Station 'H. Arctowski' on King George Island, South Shetland Islands.

Subadult Euphausia superba, 27 to $37 \mathrm{~mm}$ long, were caught in Admiralty Bay in early January 1983 with a ring trawl $\left(1 \mathrm{~m}^{2}, 2 \mathrm{~mm}\right.$ mesh; cod end: closed aluminium container $10 \mathrm{l}$ ) at the surface during night time. The net was trawled at 1 to 2 knots for 5 to 10 min. Actively swimming specimens were identified and transferred immediately to one of 2 maintenance systems. Some specimens were caught with a dip-net. Utmost care was taken to handle specimens gently during the procedure. Systems were designed to minimize handling.

Through-flow system. This consisted of three 801 polyethylene tanks each containing 18 submerged perspex cylinders (1.8 l) mounted on a PVC-plate with $2 \mathrm{~mm}$ pores and a removable top plate (Fig. 1). Each chamber housed one krill $(\Sigma=54)$, and was supplied with seawater (ca $0.6 \mathrm{l} \mathrm{min}^{-1}$ cylinder $^{-1}$ ) through tubing by a small pump (Eheim). The outlet pointed

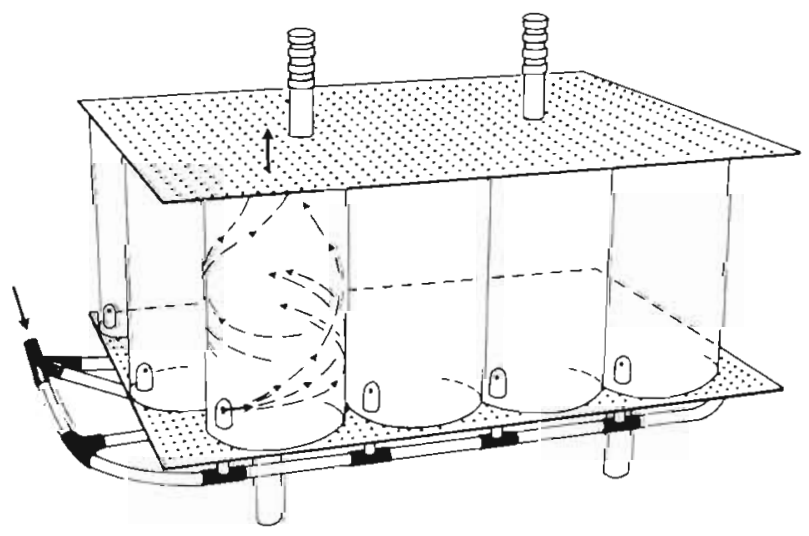

Fig. 1. Perspex chambers for maintenance of individual Euphausia superba in through-flow systems. The supply of seawater and resulting laminar current inside a chamber is shown by arrows. The PVC-top is removable. For further description see text upward, so that a circular, laminar current was created against which the krill swam. This facilitated filtering and avoided contact with the chamber walls. Fresh seawater, at $2.0 \pm 0.5^{\circ} \mathrm{C}$, containing intact natural phytoplankton, was pumped from Admiralty Bay. The pump inlet was suspended $1 \mathrm{~m}$ above the sea bottom at $6 \mathrm{~m}$ depth, $25 \mathrm{~m}$ from the shore. Seawater from this highly productive area (Tokarczyk 1986) carried much phytoplankton, and full stomachs, green hepatopancreas and faecal strings were regularly observed in the captive krill. A prototype of the system (Buchholz unpubl.) was used by Morris \& Keck (1984).

Closed system. In this case, 4 polyethylene basins contained 96 transparent plastic jars (Kautex) of 11 capacity, each housing one individual krill. Krill was fed a suspension of Chlorella spp. algae which were taken from hypertrophied freshwater ponds containing ca 9 to $15 \times 10^{6}$ cells $1^{-1}$. These cells (ca $20 \mu \mathrm{m}$ in diameter) stayed intact in seawater and were readily taken up by the krill. The jars, which had drainage holes at the bottom, were drained every $4 \mathrm{~d}$ by emptying the basins and the water was replaced. The water $\left(2.0 \pm 0.5^{\circ} \mathrm{C}\right)$ was aerated by a sharp jet of air directed against the water surface in each jar.

In both systems the overall light regime was $8 \mathrm{~h}$ darkness and $16 \mathrm{~h}$ light (dim and diffuse).

Organisation of growth experiments. By varying the feeding regime, the influence of food on moult and growth was examined.

Through-flow system: In Expt I, continuous throughflow was maintained for 2 moult cycles. Here, krill fed on particles in the seawater.

In Expt II, the through-flow was stopped after ca $50 \%$ of specimens had moulted for the first time. Subsequently, the water was recirculated and exchanged only every second to third week. Thus the specimens were starved. The water was aerated in the tank outside the chambers to avoid air-bubbles in the chambers.

Closed system: In Expt III, the food concentration was adjusted so that a dark green digestive tract was observable at all times. Each jar received $80 \mathrm{ml}$ of Chlorella spp. suspension every second day. After the third moult under these conditions, the amount fed was doubled by making the additions of Chlorella suspension daily

In Expt IV, $80 \mathrm{ml}$ of the Chlorella spp. suspension per individual was added every day.

In both systems exuviae were collected twice per day and carapace (Cpx) and uropod (Upd) length measured, from which total length (Tl) was calculated by regression analysis $(\mathrm{n}=100,24$ to $50 \mathrm{~mm}$ ):

$$
\begin{aligned}
& y_{U p d}=0.134 x_{T l}-0.288, r=0.982 \\
& y_{C p x}=0.317 x_{T l}-0.449, r=0.988
\end{aligned}
$$


Growths increments in \% of $\mathrm{Tl}$ were averaged.

Moult staging. Only live krill were staged according to Buchholz (1982). First, cuticle hardness was tested with fine forceps, particularly at the rims of the carapace. Subsequently, both outer uropods were detached and analysed under a Zeiss Photomicroscope III (Mag. 100 to $500 \times$ ) using phase contrast.

Moult stage time series. In order to determine the time course of moult stages, krill were taken from the maintenance systems and staged after a known postmoult period. Thirty specimens were taken from Expt I (1st moult interval, mean 15.6 d) and 151 krill from Expt III (1st and 2nd moult intervals, mean $16.9 \mathrm{~d}$ and $17.4 \mathrm{~d}$ respectively). Staged specimens were used for histology.

Moult staging of frozen krill. The applicability of the method to material frozen at $-80^{\circ} \mathrm{C}$ was tested. In this case fresh krill were staged, using only one uropod. After freezing, the second uropod served as a control.

Histology. The 6th abdominal segment of krill taken during the moult time series was severed and fixed in $6.25 \%$ glutaraldehyde in $0.15 \mathrm{M}$ phosphate buffer. Subsequently, photographs of semithin sections were analysed for cuticle thickness (for details see Buchholz \& Buchholz 1989).

Titre of moult hormone. Hemolymph $(50 \mu l)$ was drawn from the cardiac region with a syringe (Hamilton) and frozen at $-80^{\circ} \mathrm{C}$. Ecdysone-equivalents were determined using a radioimmuno-assay according to Goodwin (1977) (details in Buchholz 1980).

Statistics. Multiple tests were performed using the Nemenyi-test, preceded by H-test (Kruskal-Wallis) according to Sachs (1984).

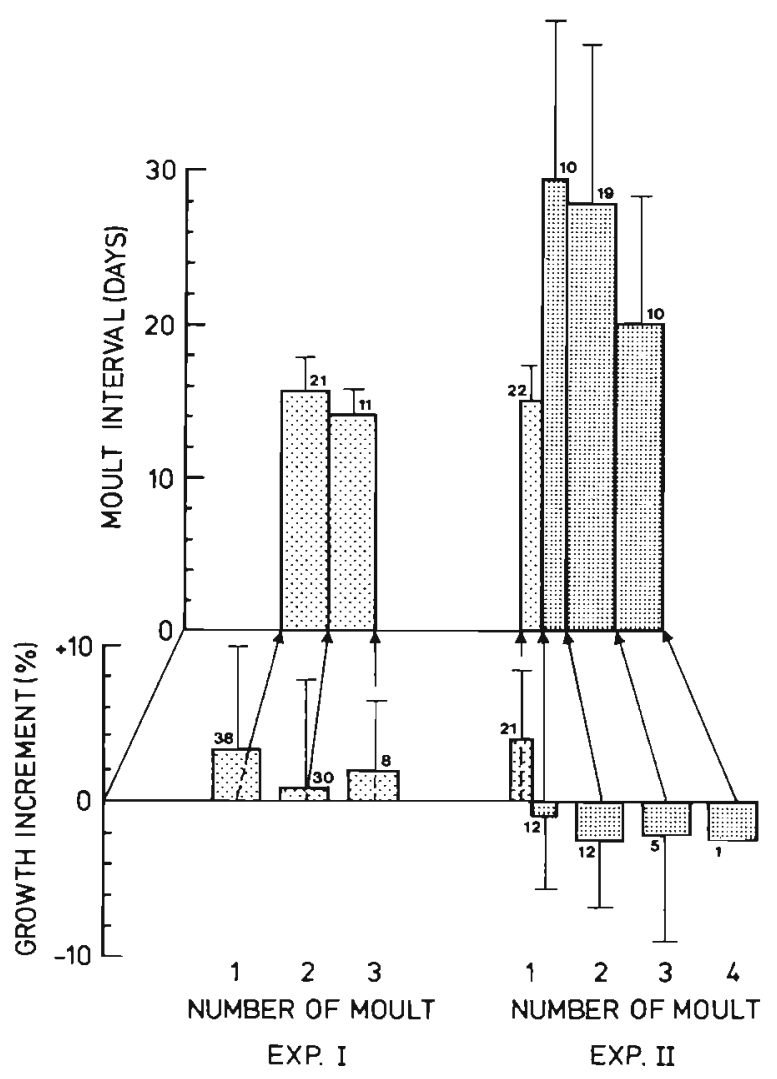

Fig. 2. Euphausia superba. Moult parameters of krill kept in through-flow aquaria. Mean moult interval (d) and linear growth increment $(\%)$ are shown for Expts I and If (standard deviations and sample size are indicated at the top of bars). The border line between 2 bars corresponds to a completed ecdysis; an arrow points from the depicted growth increment to the respective edysis. Heavily stippled bars: moult parameters of starved krill

Table 1. Euphausia superba. Data from growth experiments (Expts I to IV). M1 etc: moult number. Mean moult interval; mean growth increment following moult; mean length of experimental group; mean growth increment after first moult; mean daily growth rate. In last 4 rows only positive growth increments $(\%>0)$ were used in calculations (numbers in parentheses)

\begin{tabular}{|c|c|c|c|c|c|c|c|c|c|c|}
\hline \multirow[t]{2}{*}{ Experiment } & \multicolumn{3}{|c|}{ Moult interval (d) } & \multicolumn{4}{|c|}{ Growth increment (\%) } & \multirow{2}{*}{$\begin{array}{c}\text { Mean } \\
\text { length } \\
(\mathrm{mm})\end{array}$} & \multirow{2}{*}{$\begin{array}{c}\text { Growth } \\
\text { incr. } \\
\text { (mm) }\end{array}$} & \multirow{2}{*}{$\begin{array}{l}\text { Growth } \\
\text { rate } \\
\left(\mathrm{mm} \mathrm{d}^{-1}\right)\end{array}$} \\
\hline & $\mathrm{M} 1-\mathrm{M} 2$ & M2-M3 & M3-M4 & M1 & M2 & M3 & M4 & & & \\
\hline I. Through-flow & 15.6 & 14.1 & - & 3.2 & 0.9 & 1.9 & - & 30.3 & 0.982 & 0.063 \\
\hline II. Through-flow & 15.0 & - & - & 4.2 & - & - & - & 33.2 & 1.293 & 0.086 \\
\hline $\begin{array}{l}\text { II. Through-flow } \\
\text { (starved) }\end{array}$ & 29.3 & 28.0 & 19.5 & -0.6 & -1.2 & -1.9 & -2.5 & 33.6 & -0.324 & -0.010 \\
\hline III. Closed & 16.9 & 17.4 & 13.9 & 4.9 & 0.6 & 1.6 & 1.6 & 29.6 & 1.450 & 0.086 \\
\hline IV. Closed & 13.9 & - & - & 2.8 & -1.5 & - & - & 30.5 & 0.848 & 0.061 \\
\hline $\begin{array}{l}\text { I. Through-flow } \\
(\%>0)\end{array}$ & & & & $\begin{array}{l}6.8 \\
(25)\end{array}$ & & & & & 2.039 & 0.131 \\
\hline $\begin{array}{l}\text { II. Through-flow } \\
(\%>0)\end{array}$ & & & & $\begin{array}{l}5.3 \\
(17)\end{array}$ & & & & & 1.757 & 0.117 \\
\hline $\begin{array}{l}\text { III. Closed } \\
(\%>0)\end{array}$ & & & & $\begin{array}{c}6.4 \\
(56)\end{array}$ & & & & & 1.906 & 0.113 \\
\hline $\begin{array}{l}\text { IV. Closed } \\
(\%>0)\end{array}$ & & & & $\begin{array}{c}4.4 \\
(42)\end{array}$ & & & & & 1.342 & 0.096 \\
\hline
\end{tabular}




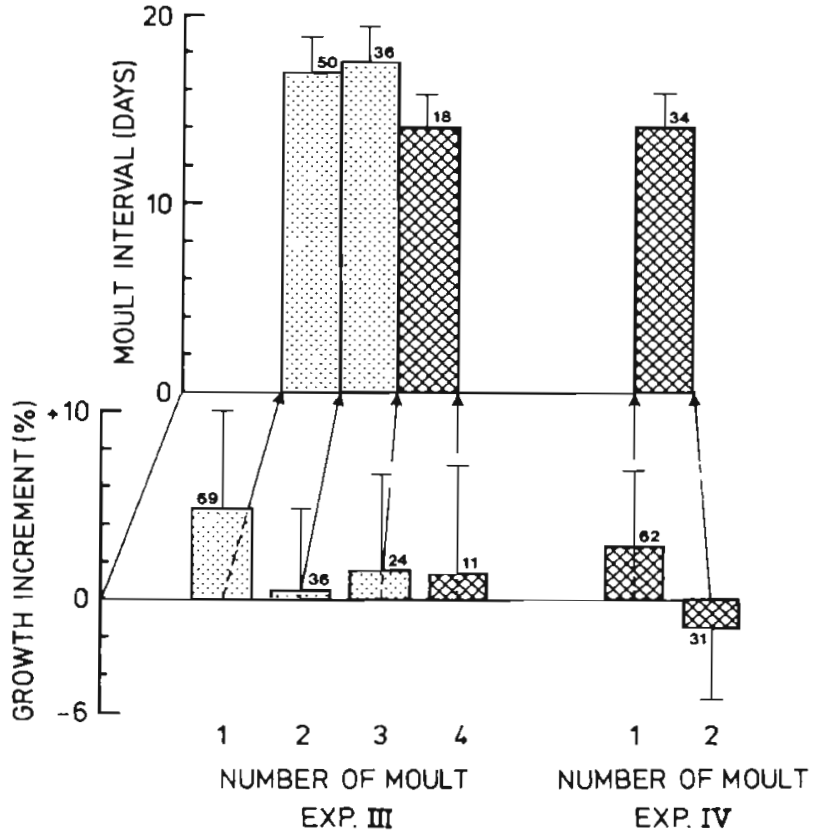

Fig. 3. Euphausia superba. Moult parameters of krill kept in closed aquaria and fed with Chlorella spp. Mean moult interval (d) and linear growth increment (\%) are shown for Expts III and IV (standard deviations and sample size are indicated at top of bars). Border line between 2 bars corresponds to a completed ecdysis; an arrow points from the depicted growth increment to the respective edysis. Cross-hatched bars: moult parameters after doubling of the amount fed

\section{RESULTS}

\section{Growth}

Mortality was low and ranged between 5 and $10 \%$ over the duration of experiments (20 to $77 \mathrm{~d}$ ).

Through-flow system. In Expts I and II (Fig. 2; Table 1), krill moulted with little variation every 14 to $16 \mathrm{~d}$. These moult intervals were statistically indistinguishable. After cutting the supply of phytoplankton, moult intervals doubled but subsequently became shorter again. The moult intervals during starvation were indistinguishable from each other but were different from those of fed krill $(p<0.05)$.
Growth increments were always greatest at the first moult (ca $3 \%$ ). Starved krill showed only negative growth of -1 to $-3 \%$.

Closed system. When fed every second day, in Expt III (Fig. 3), krill moulted steadily every 17 th day (mean). When fed daily in Expts III and IV, moult intervals were significantly shorter at $14 \mathrm{~d}(\mathrm{p}<0.05)$.

As in the through-flow experiments, first moults under laboratory conditions led to the greatest increase in body size of 5 and $3 \%$ in Expts III and IV respectively.

The time course of all moults of 96 specimens in Expt III showed an uneven distribution (Fig. 4). Modal values of groups corresponded roughly to moult intervals in Table 1. Using Bhattachayrya's method, as implemented by Gayanilo et al. (1988), mean intervals were calculated (Fig. 4, downward-pointing arrows) and all 5 moult/time-distributions could be significantly separated (separation index $\geq 2.0$ )

Modal values of growth increments of first moults (Fig. 5, black bars) lay in classes 3.1 to $6.0 \%$, that of the subsequent moults (white bars) between 0.1 and $3.0 \%$. A wide range of increments was evident: +21 to $-15 \%$.

Growth increments (Inc) diminished with size (Tl): $\mathrm{y}_{\text {Inc }}=-0.510 \mathrm{x}_{\mathrm{Tl}}+19.7, \mathrm{r}=-0.437$. Moult intervals were not dependent on size: $\mathrm{y}_{\mathrm{MI}}=-0.003 \mathrm{x}_{\mathrm{Tl}}+15.7 \mathrm{r}$ $=-0.005$.

\section{Moult cycle}

Parallel to the growth experiments, krill were taken from the experimental chambers after known post-moult periods, and the moult stages (Buchholz 1982) redefined in more detail. According to Drach (1939), the crustacean moult cycle is divided into 5 main phases (A to E):

\begin{tabular}{|c|c|c|}
\hline Postmoult: & $\begin{array}{l}\text { A } \\
\text { B } \\
\text { C }\end{array}$ & $\begin{array}{l}\text { Solidification } \\
\text { and completion } \\
\text { of cuticle laminae }\end{array}$ \\
\hline Premoult: & D & $\begin{array}{l}\text { Secretion of new cuticle, } \\
\text { setogenesis }\end{array}$ \\
\hline Ecdysis: & $E$ & Actual moult \\
\hline
\end{tabular}

The extension of stage definitions is given in Table 2 . In order to stay as closely comparable to Drach's

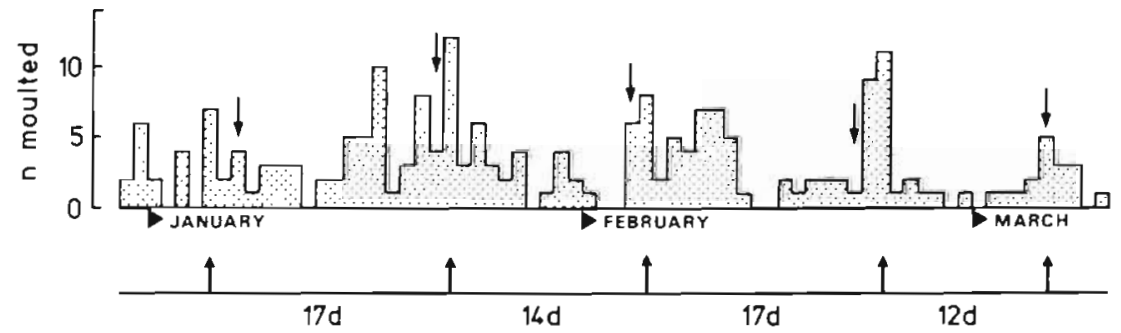

EXP. II CHLORELLA
Fig. 4. Euphausia superba. Time course of moults of krill during Expt III (Chlorella-fed). Arrows indicate maximal values of moult frequency; between these values duration (d) is given. Downwardpointing arrows represent mean times calculated according to Gayanilo et al. (1988) 
Table 2. Euphausia superba. Stages of the moult cycle

\begin{tabular}{|c|c|c|}
\hline Stage & Description & $\begin{array}{l}\% \text { of moult cycle } \\
\text { duration }\end{array}$ \\
\hline A- & $\begin{array}{l}\text { Cuticle (Cut.) very thin, specimen is unsupported outside water. } \\
\text { Uropod tissue (Upt.) not structured }\end{array}$ & 3.6 \\
\hline A & $\begin{array}{l}\text { Reinforcement of Cut. begins. Upt.: not structured. Contents of setae (Set.): coarsely } \\
\text { granular }\end{array}$ & 1.8 \\
\hline$A+$ & $\begin{array}{l}\text { Cut.: increasingly solid. Upt.: stripe pattern starts to develop. Set.: increasingly finely } \\
\text { granular }\end{array}$ & 3.0 \\
\hline $\mathrm{BC}-$ & $\begin{array}{l}\text { Cut.: still flexible at the rims of carapace and lateral sclerites of abdomen. Upt.: stripe } \\
\text { pattern fully developed. Set.: proximally still granular, otherwise clear }\end{array}$ & 9.6 \\
\hline $\mathrm{BC}$ & Cut.: completely hard. Set.: clear, no epidermal detachments & 10.2 \\
\hline $\mathrm{BC}+$ & $\begin{array}{l}\text { Epidermis begins to retract at bases of setae } \\
\text { (hemolymph lacunae }=\mathrm{C} \text { ) }\end{array}$ & 5.4 \\
\hline$D_{0}$ & Epidermis completely detached from cuticle (= apolysis) & 7.8 \\
\hline $\mathrm{D}_{\mathrm{o}}+$ & Epidermis begins to turn inside ('invagination') at bases of setae & 9.6 \\
\hline$D_{1}^{\prime}$ & Annular fold of epidermis reaches to less than $1 / 3$ of the length of the old seta into the Upt. & 5.4 \\
\hline $\mathrm{D}_{1}^{\prime \prime}$ & $\begin{array}{l}\text { Fold of invagination has reached its farthest point to } 1 / 3 \text { of the length of the old seta into the } \\
\text { Upt. }\end{array}$ & 1.2 \\
\hline $\mathrm{D}_{1}^{\prime \prime \prime}$ & As D'. Epidermis lacks a cuticle. Secondary bristles start to form & 7.8 \\
\hline $\mathrm{D}_{2}$ & New cuticle is visible & 12.0 \\
\hline $\mathrm{D}_{2}+$ & $\begin{array}{l}\text { New cuticle is clearly visible and reinforced on setae and secondary bristles. Krill is ready to } \\
\text { moult }\end{array}$ & 10.8 \\
\hline$D_{3-4}-$ & As D2. Krill starts to become soft-shelled (like BC-) & 3.6 \\
\hline$D_{3-4}$ & Cuticle completely softened & 3.6 \\
\hline $\mathrm{D}_{3-4}+$ & $\begin{array}{l}\text { Specimen is unsupported outside water. } \\
\text { New cuticle can be loosened easily from old one with forceps }\end{array}$ & 3.6 \\
\hline E & Ecdysis: krill moults within 10 to $20 \mathrm{~s}$ & \\
\hline
\end{tabular}

criteria as possible, early and late stages are named + or - instead of forcing Drach's substages to fit. Stages $B$ and $C$ cannot easily be differentiated in krill.

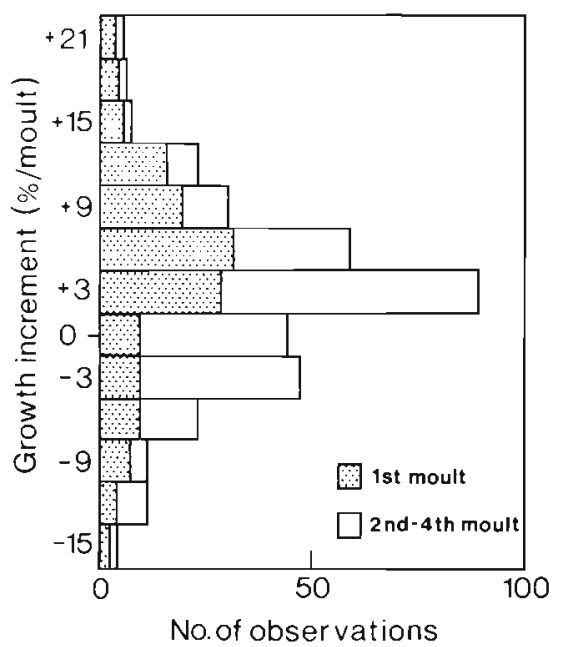

Fig. 5. Euphausia superba. Summary of all measured growth increments in percent per moult from Expts I to IV Stippled bars: first moults under laboratory conditions; white bars: second to fourth moults
According to Cuzin-Roudy (pers. comm.) the definition of stage $\mathrm{BC}+$ corresponds to stage $\mathrm{C}$, and the latter can therefore be introduced into the stage criteria.

Table 2 refers to fresh material. It is difficult to determine stages in preserved material (Buchholz 1982). Nevertheless, in deep-frozen krill (at least

Table 3. Euphausia superba. Moult stages in frozen krill

\begin{tabular}{|c|c|c|c|c|}
\hline $\begin{array}{l}\text { Main } \\
\text { stages }\end{array}$ & $\begin{array}{l}\text { Sub- } \\
\text { stages }\end{array}$ & $\begin{array}{l}\text { State of } \\
\text { cuticle }\end{array}$ & $\begin{array}{l}\text { Moult } \\
\text { phase }\end{array}$ & $\begin{array}{l}\% \text { of moult } \\
\text { cycle }\end{array}$ \\
\hline A & $\begin{array}{l}\mathrm{A}- \\
\mathrm{A} \\
\mathrm{A}+\end{array}$ & $\begin{array}{l}\text { Soft, } \\
\text { hardening }\end{array}$ & $\begin{array}{l}\text { Early } \\
\text { Postmoult }\end{array}$ & 8 \\
\hline $\mathrm{BC}$ & $\mathrm{BC}$ & Hard & $\begin{array}{l}\text { Late } \\
\text { Postmoult }\end{array}$ & 33 \\
\hline $\mathrm{D}_{1}$ & $\begin{array}{l}D_{1} \\
D_{1}+\end{array}$ & Setogenesis & $\begin{array}{l}\text { Early } \\
\text { Premoult }\end{array}$ & 18 \\
\hline $\mathrm{D}_{2}$ & $\begin{array}{l}D_{2} \\
D_{2}+\end{array}$ & Doubled & $\begin{array}{l}\text { Late } \\
\text { Premoult }\end{array}$ & 29 \\
\hline $\mathrm{D}_{3}$ & $\begin{array}{l}D_{3-4}- \\
D_{3-4} \\
D_{3-4}+\end{array}$ & $\begin{array}{l}\text { Softening, } \\
\text { soft }\end{array}$ & $\begin{array}{l}\text { Immediate } \\
\text { Premoult. }\end{array}$ & 11 \\
\hline
\end{tabular}


Table 4. Euphausia superba. Classification key for moult stages

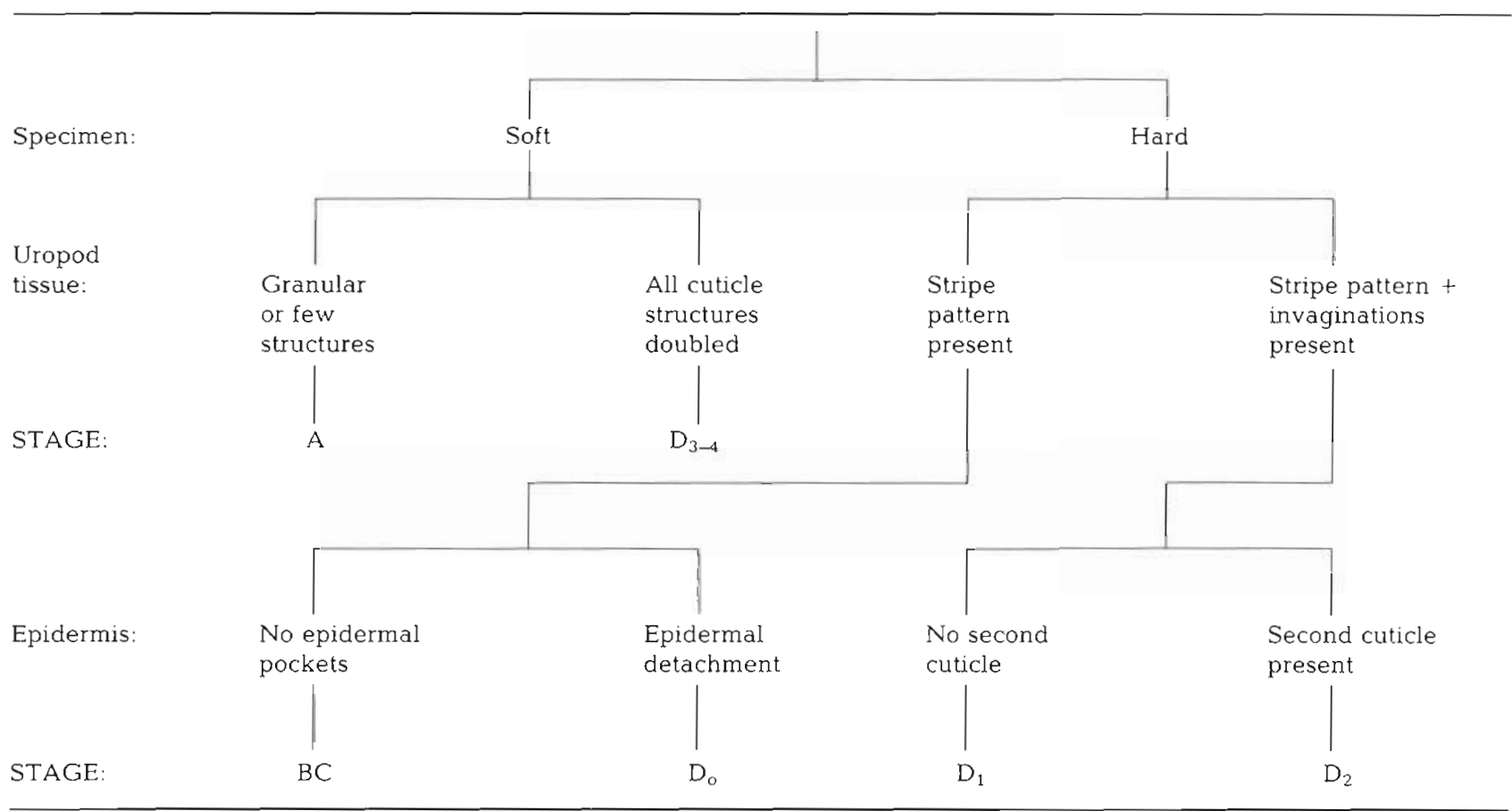

$-60^{\circ} \mathrm{C}$ ) a reduced set of stages can now be described (Table 3 ). The main difficulty occurs in stage $D_{0}$ : here the gap between old and new cuticle is often not clearly distinguishable. Stage $D_{\circ}$ therefore is included with $\mathrm{BC}$. Finer structures during $\mathrm{BC}$ and $\mathrm{D}_{1}$ are also lost.

The number of stages analysed should be adjusted to the nature of the investigation. In field studies of moulting a reduction to stages $A, B C, D_{0}, D_{1}, D_{2}, D_{3-4}$ turned out to be practical (Morris et al. 1988, Buchholz et al. 1989). To facilitate the staging procedure a classification key was designed (Table 4).
The time course of moult stages was determined as follows (for complete data set, see Fig. 6). For substages, the mean time elapsed following the previous moult was defined as the temporal stage middle. Then, the means of neighbouring stage middles were calculated, resulting in temporal stage limits. The interval in days between these limits was calculated to give the duration of the respective substage. Using the mean duration of the moult cycle (16.6 d), the percentage of the total cycle occupied by each substage was determined (Table 5).

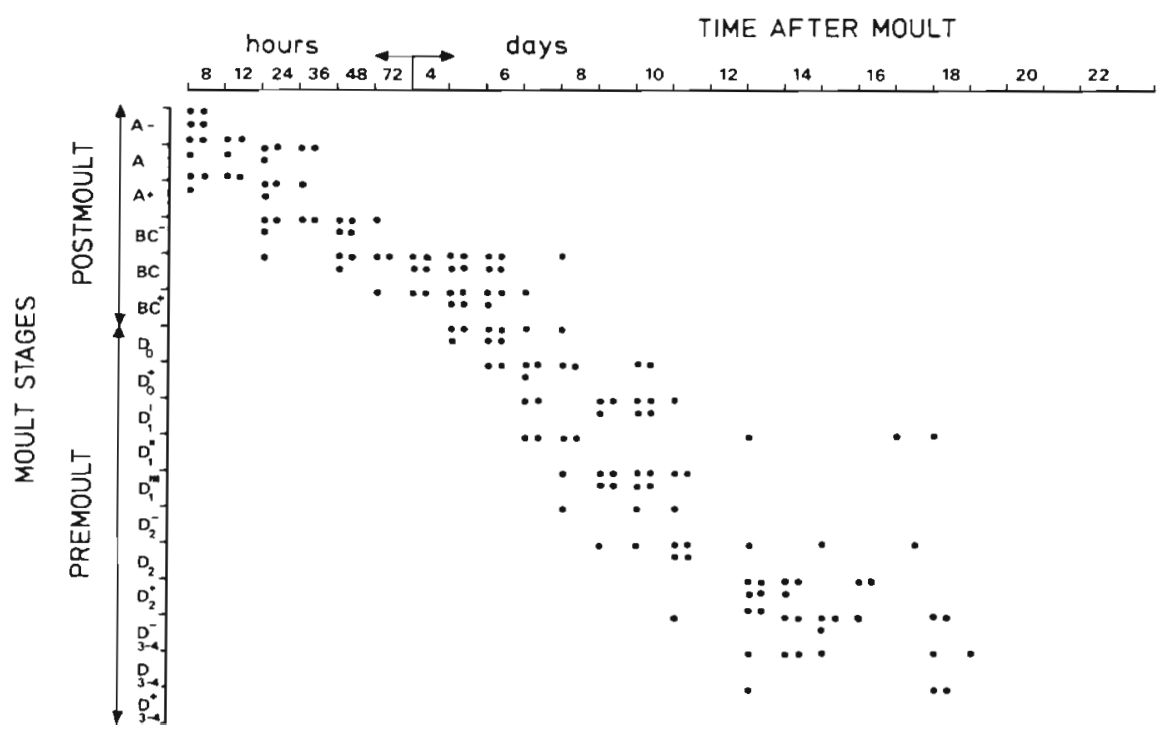

Fig. 6. Euphausia superba. Datapoints for the moult stage time series. Specimens were staged after a known post-moult period 


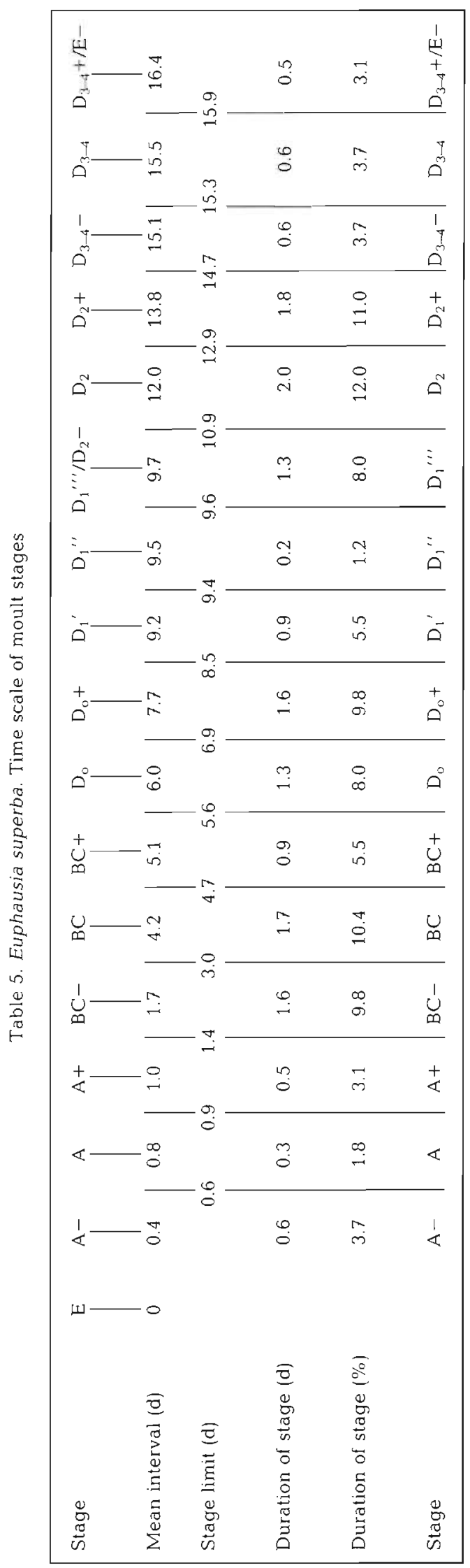

Ecdysis, the actual moult, lasts for only 10 to $20 \mathrm{~s}$. A specimen about to moult is not distinguishable by changed behaviour or reduced swimming ability. Ecdysis begins with the carapace which opens dorsally but stays attached to the exuvia at the rear end. Thoracopods and antennae are freed first, and then the abdominal cuticle is cleared by violent inflexions of the tail. Immediately after moult the krill swims normally and begins to feed ca $4 \mathrm{~h}$ later. In the aquarium, krill very rarely fed on exuviae.

\section{Moult cycle variation of cuticle thickness and titre of moult hormone}

The cuticle of krill consists of 3 layers (Buchholz \& Buchholz 1989): the very thin epi-, thicker exo-, and massive, fine-layered endocuticle. The exocuticle is

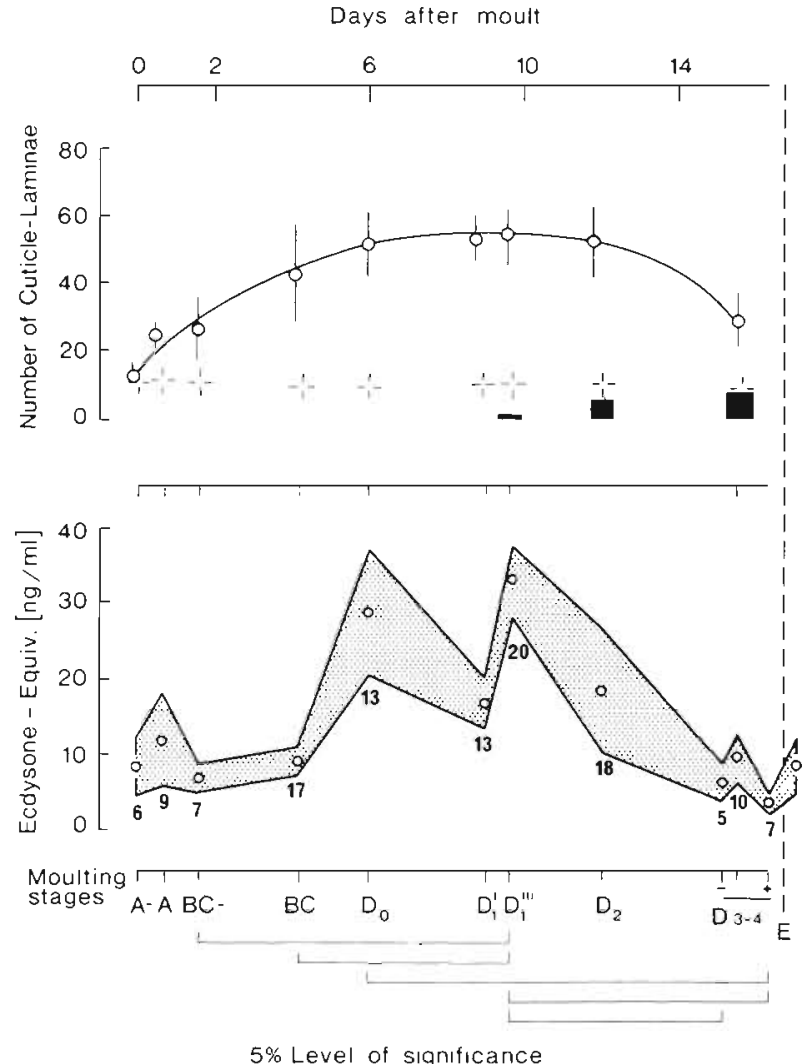

Fig. 7. Euphausia superba. Upper: Mean number of endocuticlar laminae counted in the 6 th pleomer in relation to the moult cycle (circles $\pm S D$ ); number of exocuticle laminae (crosses; SD smaller than symbol size). Number of laminae of the new exocuticle formed underneath the present cuticle is indicated as bars (+ SD). Lower: Hemolymph-titre of the moult hormone during the moult cycle. The border-lines of the hatched area connect limits of $95 \%$ confidence intervals for each mean determined (no indicated). Significant differences between means are designated by the brackets (Nemenyi- 


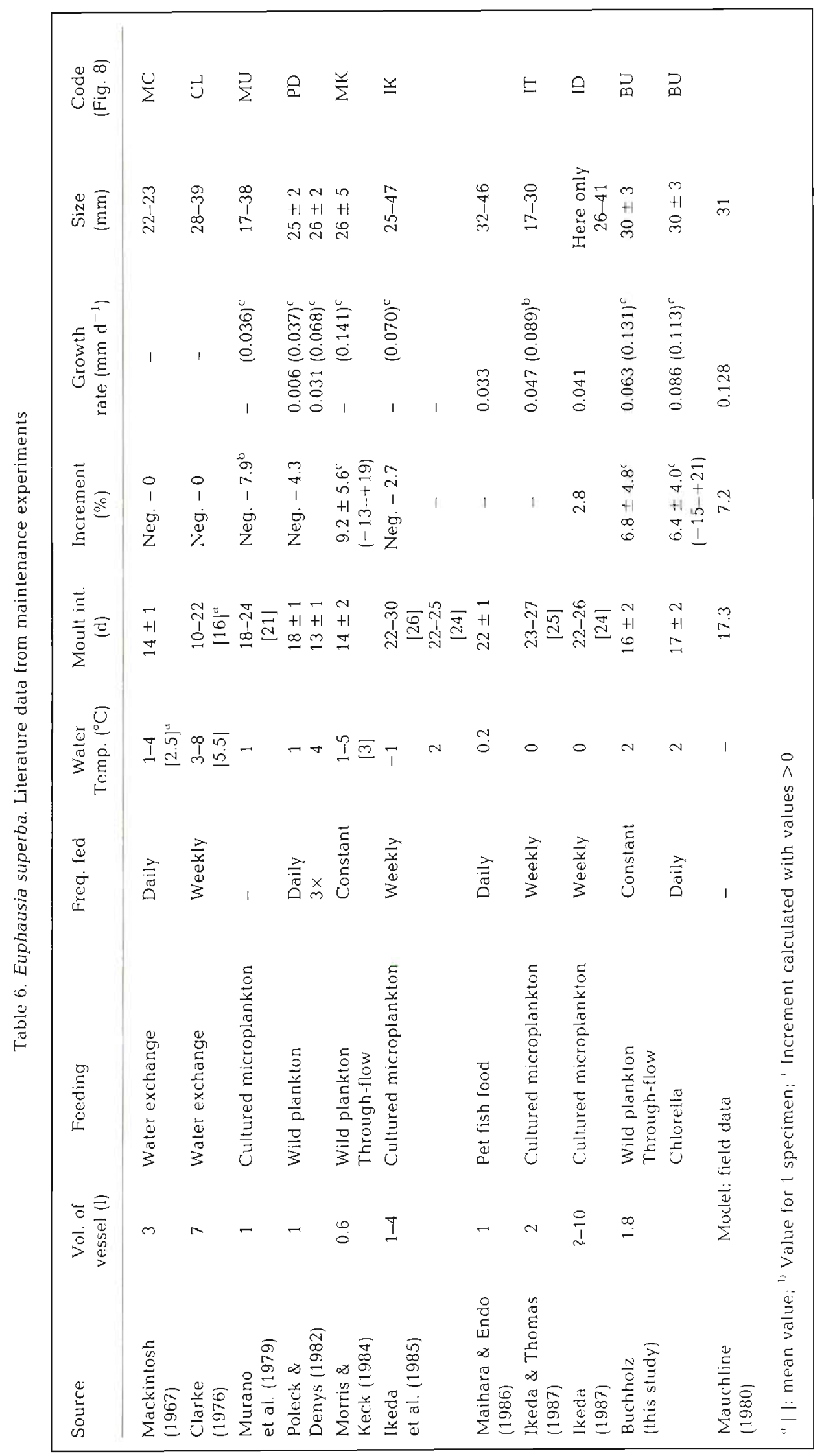


already built up underneath the existing cuticle from stage $\mathrm{D}_{1}{ }^{\prime \prime}$ onwards (Fig. 7). After ecdysis, rapid addition of endocuticular layers takes place parallel to hardening of the shell. A period of 'rest' between post- and premoult does not exist. Instead, in $D_{0}$, the epidermis retracts (apolysis) as a first step in the synthesis of the next exocuticle. A significant reduction in number of laminae (U-test, $p<0.02$ ) occurs in stage $D_{3-4}$ : material from the endocuticle is reabsorbed.

The titre of the moult hormone, determined as ecdysone-equivalents, starts with a small peak shortly after moult (Fig. 7). It rises sharply to a maximum in stage $D_{0}$ and to a second, significant peak (Nemeyni-test, $p<0.05$ ) in stage $D_{1}{ }^{\prime}$, at ca 4 times the lowest level in BC. Thereafter, the titre decreases until moult.

\section{DISCUSSION}

\section{Growth}

Doubling the amount of phytoplankton supplied to the closed system aquaria increased the moult frequency. By contrast, reduction of the food supply in the open system increased the length of moult intervals. In both experiments a close correlation between moult frequency and nutritional condition of the krill is apparent.

As far as the suitability of food organisms is concerned, the initial dosage of Chlorella spp. was not sufficient to obtain a moult frequency similar to that of the open circuit aquaria. Only when the amount of Chlorella spp. was doubled did the moult intervals become comparable to those of the krill kept in the through-flow aquaria with their constant supply of wild plankton.

The first moult under laboratory conditions was always characterized by the greatest moult increment. This diminished in consecutive moults, and under starvation conditions became negative. Negative growth can even be seen in the second moults in Expt IV (Fig. 3) in fed individuals. Apparently, the moult increment is more sensitive to maintenance-induced effects than the moult interval. A similar effect was also noted by Morris \& Keck (1984), who used a prototype of the open circuit system. The range of growth increments was similar in both maintenance systems used here.

Apparently, krill reacts to changes in feeding conditions in 2 ways: by altering the moult interval, and by changing the growth increment. This is not typical for crustaceans. Adelung (1971) reported that growth in Carcinus maenas is only regulated by altering the moult interval (see also Hartnoll 1982 for other crustaceans). Krill obviously adapts both growth parameters to the prevailing nutritional situation (cf. Buchholz 1983. Thomas \& Ikeda 1987). The wide range of growth increments from -15 to $+21 \%$ particularly indicates the plasticity of krill growth.
Moult synchrony between individuals (cf. Mackintosh 1967, Clarke 1976) was observed in both laboratory experiments and the field (Buchholz 1985, Morris 1985). The uneven distribution of moults in the time course of Expt I substantiates these observations: the spacing between modal values corresponds roughly to the moult intervals measured. The first peak of simultaneous moults occurred $7 \mathrm{~d}$ after the start of the experiment, which is about the temporal middle of a moult interval. Hence 'shock-moulting' as a captureinduced or maintenance artifact (Clarke 1976) is probably not the cause of the apparent moult synchrony in the present experiments.

Table 6 summarizes literature data on maintenance experiments with Antarctic krill. Usually, krill were kept in glass vessels of 0.5 to $10 \mathrm{l}$ and fed on natural plankton either by frequent water exchange or by adding plankton from cultures. Temperatures ranged from -1 to $+4^{\circ} \mathrm{C}$, with the exception of Clarke (1976) where varying temperatures of up to $8^{\circ} \mathrm{C}$ were employed. Although this range is generally narrow, moult interval and temperature are clearly interdependent (Fig. 8). These results explain the wide range of moult intervals from $30 \mathrm{~d}$ (Ikeda \& Thomas 1987) to $13 \mathrm{~d}$ (Poleck \& Denys 1982). However, growth increments vary considerably. Often, increments are not noted in the papers cited, and therefore seem to be underestimated as a factor governing growth. In the majority of papers, negative or stagnant growth predominates. The highest values of growth increments occurred in Murano et al. (1979; single value), Morris \& Keck (1984) and the present results (Table 6). Growth increments are poorly correlated with temperature $(r<0.05)$. Apparently, moult increments are less influenced by temperature than are moult intervals. However, inadequate maintenance methods may strongly influence the moult increment.

A common way of expressing growth rates is in units of $\mathrm{mm} \mathrm{d} \mathrm{d}^{-1}$, although this is not appropriate for the typical saltatory growth pattern in crustaceans. Overall, krill grows slowly (Table 6). Rates range from negative or no growth (Mackintosh 1967, Clarke 1976, Murano et al. 1979, Ikeda et al. 1985) up to $0.031 \mathrm{~mm} \mathrm{~d}^{-1}$ (Poleck \& Denys 1982) and $0.047 \mathrm{~mm} \mathrm{~d}^{-1}$ (Ikeda \& Thomas 1987). Present data of $0.086 \mathrm{~mm} \mathrm{~d}^{-1}$ (Expt III; Table 1) are substantially higher. When only maximal rates, omitting zero or negative growth (Table 1 , values in brackets), are recalculated, the general picture does not change: the maximal values of the preliminary study (Morris \& Keck 1984) and the present value of $0.131 \mathrm{~mm} \mathrm{~d}^{-1}$ are an order of magnitude higher than other data. Furthermore, the latter value corresponds well with a theoretical growth rate calculated from field growth data by Mauchline (1980) of $0.128 \mathrm{~mm} \mathrm{~d}^{-1}$ for a hypothetical individual of $32 \mathrm{~mm}$ length. The experi- 
mental value therefore may approach the field situation (see also Rosenberg et al. 1986). Growth rates expressed in length can easily be converted to weight using the relationships in Morris et al. (1988).

Various effects may account for the discrepancy in experimental growth rates. The specific construction of maintenance systems may have a great influence, particularly if specimens have to be handled frequently, e.g. for water exchange. This may disturb growth, although such effects are difficult to assess. The influence of temperature and the quality of food are probably easier to control.

The maintenance temperatures of Morris \& Keck (1984) of $3^{\circ} \mathrm{C}$ and the value used here of $2^{\circ} \mathrm{C}$ are in the higher range of experimental data, apparently resulting in relatively high moult frequencies. On the other hand, Poleck \& Denys (1982) kept their specimens at $4{ }^{\circ} \mathrm{C}$ and observed a maximal growth rate of $0.068 \mathrm{~mm}$ $\mathrm{d}^{-1}$, which is only half the rate of $0.131 \mathrm{~mm} \mathrm{~d}^{-1}$ in the present open circuit experiment. Apparently, the negative effects of the specific maintenance situation may have overridden the positive influence of the high temperature. Such interdependences cannot be excluded in the other studies.

The highest growth rates were reached in the open circuit system with its continuous supply of natural phytoplankton. Feeding on Chlorella spp. also appears to be favourable for krill, indicating that this alga is highly nutritious. The round shape of the cells facilitates their uptake. If the quality of food organisms essentially determines experimental growth rates, this would substantiate the high interdependence of nutrition and growth in krill. Apparently, Euphausia superba adapts its growth to the specific maintenance conditions, while the quality of food further influences growth rates.

As the specific experimental set-up and the quality of food both have an effect on growth rates in the laboratory, particular care should be taken to extrapolate slow and negative growth in the aquarium to the field situation. Negative growth may only be an indication of suboptimal maintenance conditions, and thus mainly be an artifact. Alternatively, it is only short termed, and an effect of plasticity of krill growth parameters. Negative growth was considered by Ikeda \& Dixon (1982) to be an overwintering strategy in the field. Furthermore, Murano et al. (1979), Poleck \& Denys (1982), and Ikeda et al. (1985) concluded from laboratory growth studies that krill exhibits abnormally slow growth' in general. In contrast, the data presented here indicate laboratory growth which corresponds with data from field investigations (Table 6; Rosenberg et al. 1986, Buchholz et al. 1989). Nevertheless, for a pelagic animal any maintenance situation is unnatural, so that laboratory studies remain problematic. Siegel (1986) compared a life-cycle growth curve from field studies on Euphausia superba with a similar curve for Meganyctiphanes norvegica, a boreal euphausiid from the Scandinavian Kattegat (Boysen \& Buchholz 1984). Both curves run parallel, with equal growth rates, with the only difference, that the Northern krill dies at an age of 2.5 years, whereas the Antarctic krill continue to grow until an age of ca. 5 years (Siegel 1986). Apparently, E. superba does not grow slower than the euphausiid from temperate waters. This comparison substantiates the fast growth rates in the Antarctic krill from the present laboratory study

The high growth rate, at least during summer, may be associated with the pelagic way of life of krill. The distribution of Antarctic phytoplankton is extremely patchy (El Sayed \& Weber 1982). Krill swarms therefore have to cover great distances to detect areas of high plankton production. This is made possible by the high swimming speed characteristic of krill (Kils 1982). However, the speed of locomotion is a direct function of body length. Therefore, it is physiologically advantageous for krill to grow fast. The results presented here indicate that, when krill encounters favourable feeding conditions, growth is immediately initiated by simultaneously increasing moult frequency and moult increment. Accordingly, large size, high swimming speed and plastic growth are mutually dependent. This physiological phenomenon may be a crucial selective advantage for the Antarctic krill, and may have led to it becoming one of the most successful marine species.

The results indicate that Antarctic krill only partly fit the classical scheme of polar adaptation (Dunbar 1968): slow growth generally leading to long life and gigantism. In krill, summer growth, at least, is fast, whereas the presumed longevity of 5 yr and large maximal body size of $6 \mathrm{~cm}$ (Siegel 1986) appear to be polar features. The apparent physiological efficiency necessary for fast growth or high motility is still an enigma.

The high flexibility of the growth parameters implies difficulties in constructing reliable length-frequency correlations; regional krill cohorts will grow differently due to the local availability of phytoplankton. Strong regional differences in size classes of krill are often reported (Jazdzewski et al. 1978, Makarov 1983). Regional length maxima can then be easily misinterpreted as year classes in population analyses (cf. Makarov 1983). The plasticity of growth may explain why estimates of longevity and production of krill are still uncertain (Siegel 1986).

\section{Moult cycle}

A major aim of the current work was to integrate an investigation of krill growth in the laboratory with study of the moult itself and the timing of the moult 


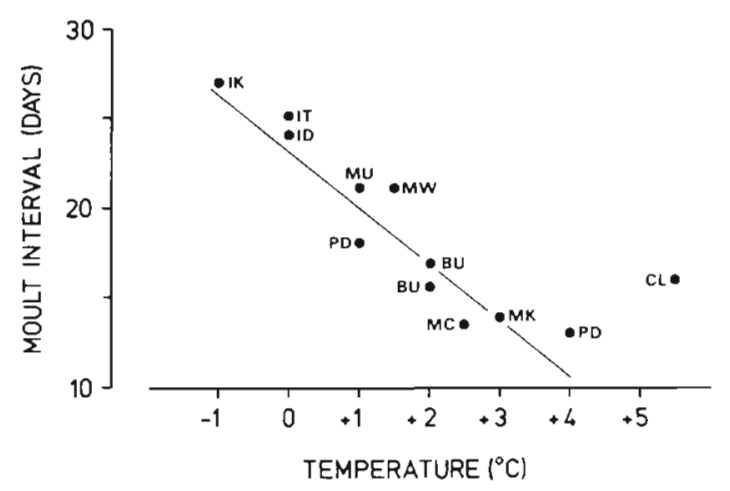

Fig. 8. Euphausia superba. Interdependence of moult interval (d) and maintenance temperature $\left({ }^{\circ} \mathrm{C}\right.$ ). Codes for literature data are given in Table 6. (Regression line shown excludes value $C L$, see text; intercept $=23.21$, slope $=-3.04, r^{2}=0.92$ )

cycle. In growth experiments moulting occurred regularly and steadily. This is a necessary precondition for accurate determination of the time course of the moult stages. The annotated table of stage criteria (Table 2) should further facilitate the application of the moult staging system. Stage $\mathrm{C}$ may if desired be introduced to replace stage $\mathrm{BC}+$. The morphological staging criteria closely match the cyclical histological processes seen in the integument. In particular, a 'rest' phase between the postmoult phase and the onset of the next preecdysis does not exist. Both phases merge without transition or 'intermoult' period. Rapid initiation of the next pre-ecdysis after completed moults, leads to a high moult frequency. The decrease in laminae number $(p<0.05)$ from stage $D_{2}$ to $D_{3-4}$ explains the concomitant softening of the exoskeleton during the latter phase: cuticular material is massively resorbed prior to ecdysis (see also Buchholz \& Buchholz 1989).

The close match between morphological and histological events verifies the applicability of the staging system. Furthermore, the varying titre of the moult

Table 7. Euphausia superba. Comparison of stage duration as percent of total moult cycle

\begin{tabular}{|c|c|c|}
\hline Stage & $\begin{array}{c}\text { Nicol \& Stolp } \\
(1990)\end{array}$ & Present study ${ }^{a}$ \\
\hline A & 4 & 5 \\
\hline $\mathrm{B}-\mathrm{C}$ & 44 & $28^{\mathrm{b}}$ \\
\hline$D_{0}$ & 12 & 17 \\
\hline $\mathrm{D}_{1}^{\prime}$ & 6 & 5 \\
\hline $\mathrm{D}_{1}^{\prime \prime}$ & 2 & 1 \\
\hline$D_{1}^{\prime \prime \prime}$ & 8 & 8 \\
\hline $\mathrm{D}_{2}$ & $17-20$ & 23 \\
\hline$D_{3-4}$ & 7 & 11 \\
\hline \multicolumn{3}{|c|}{$\begin{array}{l}\text { a For detailed stages see Table } 2 \\
\text { b }\end{array}$} \\
\hline
\end{tabular}

hormone, which changes in a regular and reproducible way, substantiates the link between morphological and physiological processes. The course of the titre is typical for crustaceans (Adelung 1971) with 2 hormone maxima. The first maximum coincides with apolysis, i.e. detachment of the epidermis from the old cuticle, while the second maximum coincides with the onset of synthesis of the new exocuticle. The maximal value of $38 \mathrm{ng} \mathrm{ml}^{-1}$ is comparable with values in the crayfish Orconectes limosus (Jegla et al. 1983). Unfortunately, the titre's relatively complex course prevents its use as a means of determining moult stages by ecdysteroid concentrations alone (Buchholz 1982).

Timing of the moult cycle in Euphausia superba was recently undertaken by Nicol \& Stolp (1990). The basis was a catalogue of photographs of the morphological development of the uropods in close accordance with the staging criteria of Buchholz (1982). In contrast to the process here, krill was permitted to proceed to ecdysis following staging. Nevertheless, there is a close match between the 2 approaches in the proportional durations of the main stages (Table 7). However, the data presented here add a finer resolution of substages, particularly in the phases immediately before and after ecdysis (Table 2). The criterion of differentiation is cuticle hardness, which cannot be assessed by photographic analysis alone. Good knowledge of the temporal sequence of events shortly before and after ecdysis is particularly important because the most dramatic physiological and morphological changes during the moult cycle occur during this time.

The only major difference between the 2 sets of data is the duration of stage BC: $44 \%$ in Nicol \& Stolp (1990) vs $28 \%$ here. This might either be an effect of temperature, since the authors kept krill at $0^{\circ} \mathrm{C}$ instead of $2{ }^{\circ} \mathrm{C}$, or result from different feeding regimes. Stage $B C$ in krill includes substage $C_{4}$, which is the intermoult phase or a specific 'resting phase' in other crustaceans (Drach 1939, Passano 1960, Hartnoll 1982), and can be extended when environmental conditions become unfavourable. However, histological and enzymatic evidence (Buchholz \& Buchholz 1989), as well as results from a field study of growth and moult (Buchholz et al. 1989), indicate that in krill no specific moult stage usually varies in length, but rather overall shortening or extension of the complete moult-cycle accounts for changes in the moult interval. A direct experimental test is desirable, where temperature and feeding regime can be varied.

Essentially unhindered motility during the phase of the actual moult and extremely fast ecdysis are unusual for a crustacean. Most crustaceans hide in a sheltered place and stay there to moult for periods from hours to several days. Ecdysis itself may take hours (Passano 1960). Fast ecdysis in krill may be interpreted as an 
adaptation to a pelagic way of life. The underwater weight of krill is considerable (Kils 1982) so individuals would sink quickly into oxygen-depleted depths if ecdysis and the associated loss in motility lasted even minutes. Furthermore, krill swarms would disintegrate if swimming speed were appreciably reduced during ecdysis, because moulting specimens would fall back in relation to the fast-moving swarm.

The results on growth and moulting in a single laboratory study demonstrate the physiological and ecological interdependence of these 2 important factors. Hopefully these data will be helpful in further studies of krill biology and in improving understanding of the situation of pelagic crustaceans in general.

Acknowledgements. Many thanks are due to Drs T. Ikeda, D. J. Morris, S. Nicol and J. Watkins for lively discussions. [ am particularly grateful for a fruitful exchange of ideas to Drs Cornelia Buchholz and Janine Cuzin-Roudy. Prof. S. RakusaSuszczewski made possible a 3 mo stay at the Polish Antarctic Station ' $\mathrm{H}$. Arctowski', where I enjoyed the cheerful company of my 9 friends of the 6th Polish Antarctic expedition, also including 'the German group, Prof. D. Adelung and Drs G. Dieckmann and $W$ Reichardt. Chilean authorities facilitated transport to the station and Prof. G. Hempel sent FS Polarstern' on her maiden voyage on a detour to King George Island for the return journey. The work was part of a habilitation thesis of the University of Kiel (Buchholz 1988). Dr R. Wilson corrected the English. Supported by the German Research Council (DFG), grant Bu 548/1/1-3

\section{LITERATURE CITED}

Adelung, D. (1971). Untersuchungen zur Häutungsphysiologie der dekapoden Krebse am Beispiel der Strandkrabbe Carcinus maenas. Helgoländer wiss. Meeresunters. 22: $66-119$

Boysen, E., Buchholz, F. (1984). Meganyctiphanes norvegica in the Kattegat. Studies on the annual development of a pelagic population. Mar Biol. 79: 195-207

Buchholz, F. (1980). Untersuchungen zum Ecdysonstoffwechsel der Strandkrabbe Carcinus maenas L. Dissertation, Univ. Kiel

Buchholz, F. (1982). Drach's molt staging system adapted for euphausiids. Mar. Biol. 66: 301-305.

Buchholz, F. (1983). Moulting and moult physiology in krill. In: Schnack, S. B. (ed.) On the biology of Euphausia superba. Proc. Seminar Rep. of the Krill Ecology Group. Bremerhaven. Ber. Polarforsch. Sonderh. 4: 81-88

Buchholz, F. (1985). Moult and growth in euphausiids. In: Siegfried, W. R., Condy, P., Laws. R. M. (eds.) Antarctic nutrient cycles and tood webs. Proc. 4th Symp. Antarct. Biol. Sprnger, Berlin, p. 339-34.5

Buchholz, F. (1988). Zur Lebensweise des antarktischen und des nordischen Krills Euphausia superba and Meganyctiphanes norvegica. Ber. Inst. Meeresk. Univ. Kiel 1.85: $256 \mathrm{pp}$.

Buchholz, C., Buchholz, F. (1989). The ultrastructure of the integument of a pelagic crustacean: moult cycle related studies on Euphausia superba. Mar Biol. 101 355-365

Buchholz, F., Morris, D. J., Watkins, J. L. (1989). Analyses of field moult data: prediction of intermoult period and assessment of seasonal growth in Antarctic krill, Euphausia superba Dana. Antarct. Sci. 1. 301-306

Clarke, A. (1976). Some observations on krill (Euphausia superba Dana) maintained alive in the laboratory. Br. Antarct. Surv. Bull. 43: 111-118

Drach, P. (1939). Mue et cycle d'intermue chez les crustacés décapodes. Anr. Inst Océanogr. Monaco 19: 103-391

Dunbar, M. J. (1968). Ecological development in polar regions. A study in evolution. Prentice-Hall, Inc., Englewood Clitfs

El-Sayed, S. Z., Weber, L. H. (1982). Spatial and temporal variations in phytoplankton biomass and primary productivity in the south-west Atlantic and Scotia Sea. Polar. Biol. 1: $83-90$

Gayanilo, F. C. $J_{T}$, Soriano, M., Pauly, D. (1988). A draft guide to the Compleat ELEFAN. ICLARM Software 2, International Center for Living Aquatic Resources Management, Manila, Philippines

Goodwin, T W (ed.) (1977). International review of biochemistry, Biochemistry of lipids, II. Univ. Park Press, Baltimore

Hartnoll, R. G. (1982). Growth. In: Abele, L. G. (ed.) The biology of Crustacea, Vol. 2. Academic Press, New York p. 111-196

Hempel, G. (1970). Antarctic. In: Gulland, J. A. (ed.) The fish resources of the ocean. FAO Fish. Tech. Pap. 97: 197-203

Ikeda, T (1987). Mature Antarctic krill (Euphausia superba Dana) grown from eggs in the laboratory. J. Plankton Res. 9: $565-569$

Ikeda, T., Dixon, P. (1982). Body shrinkage as a possible overwintering mechanism of the Antarctic krill (Euphausia superba Danal. J. exp. mar. Biol. Ecol. 62: 143-151

Ikeda, T., Dixon, P., Kirkwood, J. (1985). Laboratory observation of moulting, growth and maturation of the Antarctic krill (Euphausia superba Dana). Polar Biol. 4: 1-18

Ikeda, T., Thomas, P. G. (1987). Moulting interval and growth of juvenile Antarctic krill (Euphausia superba) fed different concentrations of the diatom Phaeodactylum tricornutum in the laboratory. Polar Biol. 7. 339-343

Jazdzewski, K., Dzik, J , Porebski, J., Rakusa-Suszczewski, S., Witek, Z., Wolnomiejski, N. (1978). Biological and populational studies on krill near South Shetland Island, Scotia Sea and South Georgia in the summer 1976. Pol. Arch. Hydrobiol. 25: 607-631

Jegla, T. C., Ruland, C., Kegel, G., Keller, R. (1983). The role of the $Y$-organ and cephalic gland in ecdysteroid production and the control of molting in the crayfish Orconectes limosus. J. comp. Physiol. 152: 91-95

Kils, U. (1982). Size dissociation in krill swarms. In Rheinheimer, G., Flügel, H., Lenz, J., Zeitzschel, B. (eds.) Lower organisms and their role in the food web. Kiel. Meeresforsch. Sonderh. 5: 262-263

Mackintosh, N. A. (1967). Maintenance of living Euphausia superba and frequency of moults. Norsk. Hvalfangsttid. 56: $97-102$

Maihara, Y., Endo, Y (1986). Laboratory observations on molting and growth of Antarctic krill, Euphausia superba Dana. (Extended abstract). Mem. natn. Inst. polar Res., Tokyo, Spec. Iss. 44: 125-127

Makarov, R. R., (1983). Geographical aspects in the investigation of the life history of Euphausia superba Dana. Ber. Polarforsch. Sonderh. 4: 47-57

Mauchline, J. (1980). The biology of mysids and euphausids. Adv. mar. Biol. 18: 1-677

Morris, D. J. (1985). Integrated model of moulting and feeding of Antarctic krill Euphausia superba off South Georgia. Mar. Ecol. Prog. Ser 22: 207-217

Morris, D., Keck, A. (1984). The time course of the moult cycle 
and growth of Euphausia superba in the laboratory. A preliminary study. Meeresforsch. 30: 94-100

Morris, D. J., Watkins, J. L., Ricketts, C., Buchholz, F., Priddle, J. (1988). An assessment of the merits of length and weight measurements of Antarctic krill Euphausia superba. Br. Antarct. Surv. Bull. 79: 27-50

Murano, M., Segawa, S., Kato, M. (1979). Molt and growth of the Antarctic krill in laboratory. Trans. Tokyo Univ. Fish. 3: 99-106

Nicol, S., Stolp, M. (1990). A refinement of the moult-staging technique for Antarctic krill (Euphausia superba). Mar. Biol. 104: 169-173

Passano, L. M. (1960). Molting and its control. In: Waterman, T H. (ed.) The physiology of Crustacea, Vol. 1 Academic Press, London, p. 473-536

Poleck, T., Denys, C. F. (1982). Effect of temperature on the molting, growth and maturation of the Antarctic krill

This article was submitted to the editor
Euphausia superba (Crustacea: Euphausiacea) under laboratory conditions. Mar. Biol. 70: 255-265

Rosenberg, A. A., Beddington, J. R., Basson, M. (1986). Growth and longevity of krill during the first decade of pelagic whaling. Nature, Lond. 324: 152-1.53

Sachs, L. (1984). Angewandte Statistik. Springer, Berlin, p. 545

Siegel, V (1986). Untersuchungen zur Biologie des antarktischen Krill, Euphausia superba, im Bereich der Bransfield Straße und angrenzender Gebiete. Mitt. Inst. Seefisch., Hamburg 38: 1-244

Thomas, P. G., Ikeda, T (1987). Sexual regression, shrinkage re-maturation and growth of spent female Euphausia superba in the laboratory. Mar. Biol. 95: 357-363

Tokarczyk, R. (1986). Annual cycle of chlorophyll a in Admiralty Bay 1981-1982 (King George Island, South Shetlands) Pol. Arch. Hydrobiol. 33(2): 177-188

Manuscript first received: July 30, 1990

Revised version accepted: October 11, 1990 